\author{
Владан 3. ЈОВАНОВИЋ* \\ Институт за српски језик САНУ \\ Београд
}

Оригинални научни рад

Примљен: 03. 11. 2017.

Прихваћен: 27. 12. 2017.

\title{
ЗБИРНИ БРОЈЕВИ У ГРАМАТИЦИ И ЛЕКСИКОГРАФИЈИ*
}

\begin{abstract}
У раду се анализирају збирни бројеви као једна од класификационих врста у систему бројева у српском језику. Узимајући у обзир чињеницу да у граматичкој литератури и описним речницима српског језика класа збирних бројева није на једнак начин појмовно и терминолошки описана, у раду је пажња посвећена појмовним, терминолошким и класификационим питањима збирних бројева у систему категорије бројева у науци о српском језику. Полазећи од резултата анализе добијених у овом раду, уз ослањање на досадашњу литературу, збирни бројеви се посматрају као једна лексичко-граматичка класа бројева на -оје (-оји) и -оро (-ори), коју повезује семантичка компонента збирности, као и део основе -ој- и -ор-. Анализа збирних бројева спроведена је у следећим областима: 1) збирни бројеви у граматичкој литератури; 2) граматичка и семантичка анализа збирних бројева на основу грађе добијене из речника и других штампаних дела, и 3) обрада и презентација збирних бројева у речницима српског језика.

Кључне речи: збирни бројеви, класификација, граматика, бројни придев, лексичко-граматичка анализа, лексикографија, српски језик.
\end{abstract}

\section{1. Увод}

Ако занемаримо изузетке, у граматикама српског језика бројеви су класификовани као променљива врста речи, којима се означава колико има онога што значи именица уз коју стоје или у којем се реду међу другим појмовима налази дати појам. Такође, у њиховом опису наглашава се да су неки од њих променљиви, а неки нису. Узевши у обзир и ставове појединих аутора који су, полазећи од морфолошке, синтаксичке и семантичке сродности с неким

*vladjovanovic@hotmail.com

** Рад је написан у оквиру пројекта Лингвистичка истраживања савременог српског језика и израда Речника српскохрватског књижевног и народног језика, бр. 178009, који финансира Министарство просвете, науке и технолошког развоја Републике Србије. 
другим врстама речи, бројеве као врсту доводили под сумњу, у овом раду сагласни смо са становиштем већине проучавалаца који сматрају да постојање истих граматичких категорија није довољан разлог да одређене значењске врсте бројева придодајемо именицама, прилозима, придевима (в. Зељић 2016: 17).

Основно полазиште у овом раду јесте то да проблем описа и класификације бројева није само граматички, већ и лексикографски, поготово због тога што се од лексикографије очекује да у виду лингвистичког конструкта, какав је дескриптивни речник једног језика, покаже системност и доследност у опису речи, а самим тим класа којима оне припадају, категорија које садрже итд. Прегледавши литературу о (збирним) бројевима у српском језику, познатије граматике савременог српског језика и лингвистичке речнике односно енциклопедије (в. Белић 2000а, 2000б; Зељић 2016; Једличка 1977-1979; Кликовац 2002; Лалевић 1951; Ломпар 2016; Маретић 1963; Мразовић 2009; Пипер/Клајн 2014; Поповић 1979; Радовић Тешић 2011; Симић ${ }^{2} 2001$; Станојчић/Пецо 1972; Станојчић/Поповић 1997; Станојчић 2008; Стевановић 1970; Стефановић 2017; Стијовић 2013; Тафра 1989), уочили смо да постоји разноликост у погледу њихове класификације, односно појмовног/терминолошког одређења класа и поткласа, па чак и у погледу нормативних препорука. Разлика у граматичком приступу и опису категорије бројева у српском језику одражава се и на њихову лексикографску обраду, што се може утврдити испоређењем трију најважнијих речника српског језика - Академијиног (САНУ) и двају Матичиних (РМС и РСЈ). На основу увида у лексикографски опис бројева у поменутим речницима, приметили смо да су разлике у њиховом представљању најочигледније код збирних бројева у облицима множине. Док су у једнима множински облици узимани као множина збирних бројева (РСАНУ, РМС), у другима су множински облици издвојени као посебна класа чији су номинативни облици дати у форми одредничких речи (РМC).

Анализа збирних бројева у раду обухватила је следећа основна питања: збирни бројеви у граматичкој литератури (с посебним освртом на класификацију бројева из угла збирних бројева), граматичка и семантичка анализа збирних бројева на основу грађе добијене из речника и других штампаних дела, те обрада и презентација збирних бројева у речницима српског језика.

\section{2. Поглед на класификацију бројева (из угла збирних бројева)}

Класификација бројева, уз терминологију, тј. именовање њихових врста, јесте једна од средишњих тема у литератури о бројевима. Увидом у домаћу граматичку литературу, уочавамо да се класификација бројева разликује од једне до друге граматике, али да, и поред тога, неки појмови и термини остају као константе, нпр. традиционални називи за врсте бројева као што су основни, редни, збирни. Када је реч о збирним бројевима, у литератури се као 
спорно показује питање множине збирних бројева, односно постојање бројних придева као посебне врсте (в. Зељић 2016: 27). На пример, Љ. Поповић у систему бројева разликује кардиналне бројеве као речи које служе за нумеричку квантификацију од редних бројева, а у кардиналне убраја основне или главне бројеве, збирне (колективне) бројеве, бројне именице на -ица и бројне придеве, стављајући напомену да ове последње неки граматичари сматрају множином од броја један и од збирних бројева (Поповић 1979: 4). На другој страни, у најновијој граматици српског језика (Пипер/Клајн 2014) дата је до сада најбројнија подела на врсте бројева (основни, редни, збирни, општи, мушколични, разломачки, бројеви за приближност (приближни бројеви)), где су бројни придеви дати у оквиру класе збирних бројева. ${ }^{1}$

У новијој, као уосталом и у старијој литератури, збирни бројеви нису на једнак начин представљени и описани. Општеузев, збирни бројеви су представљени као шира бројна врста, која подразумева како облике у једнини у именичком морфемском лику, тако и множинске облике у придевском морфемском лику у сва три рода. Насупрот овом одређењу стоји и такво које из класе збирних бројева издваја множинске облике, означавајући их термином бројни придеви ${ }^{2}$. На основу прегледане литературе издвојићемо и прокоментарисати најчешће приступе класификацији и појмовном одређењу бројних врста из угла збирних бројева.

1) Збирни бројеви су узети као једна врста, са граматичком једнином (именичком) и множином (придевском), што значи да је, на пример, могуће казати троје пријатеља, а у промени мењати дао је нешто тројим пријатељьия, разговарао је са тројим пријатељима итд. без разлике у значењу. ${ }^{3}$

Ово је, рекли бисмо, доминантан приступ бројевима у српској граматици. А. Белић и М. Стевановић бројеве деле на основне, збирне и редне (Белић 2000б; Стевановић 1970), а сличну класификацију, укључујући и терминолошки апарат, налазимо и данас у најпознатијим српским граматикама и приручницима. ${ }^{4}$ У Граматици Станојчић/Поповић (1997: 96) пише да „збирни бројеви употребљени у облику множине одређују по броју и збир

${ }^{1}$ У књизи Г. Зељића (2016), која је у целини посвећена бројевима као врсти речи, у поглављу под насловом Класификачија бројева представљене су класификације бројева у досадашњој литератури и граматикама од Вука до данас.

2 Поједини аутори користе термин за врсту изведен из множинског облика „бројевни придев”, упркос устаљеном нормативистичком гледишту да за термин није од пресудне важности његова мотивисаност (прозирност), већ означна функција, тј. тачно и недвосмислено именовање појма у оквиру датог појмовног система и номенклатуре. Будући да термин бројни придев или бројна именица до данас несметано обављају функцију тачног означавања појма у граматичкој терминологији, не видимо разлог због којег би се они преименовали у „бројевне придеве” „бројевне именице” (в. Јовановић 2017: 296-297).

${ }_{3}^{3}$ Ова промена упоредива је са променом збирних бројева у руском књижевном језику, где су у номинативу (и акузативу кад је једнак номинативу) наставци идентични са наставцима именичке промене средњег рода једнине, док у осталим падежима имају наставке идентичне са наставцима множине заменичке, односно придевске промене: двое, двоих, двоим итд.

${ }^{4}$ А. Белић користи термин збирни придевски бројни облик за случајеве бројева уз именице које имају само множину или се употребљавају онда „када је потребно узети у коме падежу множине: именицу уз број више од један: дао сам тројим пријатељима, рекао сам тројим просиоцима, дао је четворим воловима да једу" (Белић 2000б: 168). За разлику од Белића, М. С. Лалевић (1951: 22-23) бројне придеве сматра посебном врстом у односу на збирне бројеве. 
предмета који значе неку целину: петора врата итд.” У Српској граматищи Р. Симића (2001: 167-168) бројеви се деле на основне (са поткласама главни и збирни) и редне. За збирне бројеве аутор каже да се односе „на конкретне скупове у којима се јединке разликују по роду: двоје - двоји, троје - троји, петоро - петори ... Збирни бројеви могу имати множинске облике ... у служби придевских речи уз именице које познају једино множину", али наводи и овај пример: двоји просиоци - двојих просилаца. У Нормативној граматици српскога језика за множинске облике збирних бројева пише следеће: „Збирни бројеви имају и придевске облике, који се употребљавају са именицама без облика за једнину, слажући се са њима по завршетку: двоја врата, троје маказе, седмора кола" (Пипер/Клајн 2013: 138). У поменутој граматици дато je, дакле, уже одређење употребе множинских облика збирних бројева у поређењу са Белићевом или Стевановићевом граматиком, пошто су из описа изостали примери придевских облика уз именице које не припадају категорији плуралија тантум (нпр. деветори синови, троји пријатељи итд.), као и они којима се исказују групе од два или више ентитета (нпр. двоје чарапе, троји просиоци итд.).

2) Бројеви на -оје и -оро у облику једнине средњег рода код једног броја аутора означени су термином збирни бројеви: троје људи, четворо деще, док се од истих бројних основа облици у придевском лику у множини одређују као посебна врста под називом бројни придеви.

На основу граматичке литературе разликујемо три начина на која су они описани: а) бројни придеви двоји, троји, десетори и сл. иду са именицама плуралија тантум, затим уз именице које казују парове (троје чарапе, четвори опанци) и „уз групе множина, умножене множине (двоји сватови, троји косиоци)" (Лалевић 1951: 23), б) бројни придеви су само они бројеви који иду уз именице pluralia tantum или пак уз именице које означавају пар нечега, нпр.: nетора врата, двоје чарапе итд. (в. нпр. Кликовац 2002: 89; Ломпар 2016: $288)$, док се, у трећем случају, 3) одређење бројних придева проширује и на случајеве обичне множине, тј. њихову употребу у промени уместо основних бројева, нпр. Говорити о четверим представама (Барић и др. 1997: 221).

3) Поред наведена два, у литератури постоји и трећи, додуше ређи, приступ, по којем бројеви у придевском облику на -ори и -оји нису бројеви, већ придеви. У граматици П. Мразовић (2009: 281) за множинске облике збирних бројева каже се следеће: „Придевски бројеви двоји, троји итд., као и редни бројеви први, други итд. јесу придеви, док се остали бројеви деле на групе: основни бројеви, збирни бројеви".

У граматикама у којима је приступ класификацији бројева овде описан под 2), бројни придеви су махом дефинисани као бројеви који конгруирају са именицама pluralia tantum, односно долазе у спојивима са речима којима се означава пар нечега. Тиме, међутим, нису исцрпене све могућности употребе множинских облика збирних бројева. Збирни бројеви у множини могу се употребити, како уосталом бележи Речник САНУ и поједине граматике, за означавање збира нечега што се исказује обичном множином (еквивалентно значењу основних бројева) или уз именице са значењем целина не само од 
два већ и више ентитета, нпр. Изабрана [је] мати Југовића, деветорих синова који су најугледнији витези косовски (Поп. П., РСАНУ, под деветоро), И он отиде, и понесе десет таланата сребра ... и десеторе стајаће хаљине (Дан. Ђ., РСАНУ, под десеторо), или, како стоји, на пример, у граматикама А. Белића и Т. Маретића, да се бројеви у множинском облику могу узети уместо основних који се не мењају, нпр.: „објавише петорим народима, рекох седморим женама, заповједисмо десеторим селима” (Маретић 1963: 223) или „дао сам [што] тројим пријатељима ... дао је [што] четворим воловима" (Белић 2000б: 168).

\section{3. Граматика и семантика збирних бројева}

Дефиниција збирних бројева, коју најчешће налазимо у граматикама и литератури, полази од њихове доминантне семантике, где се, мање-више, каже да се они употребљавају у значењу тачног броја појмова који се могу узети као једна целина. Уз опис збирних бројева даље се каже да се они везују најчешће за именице у значењу скупова младих бића, људи или животиња: двоје јагњади, троје прасади итд. или за означавање бића различитог пола. Следеће што се налази уз опис збирних бројева то је њихова променљивост по падежима. У погледу промене бројева по падежима, у овом случају промене збирних бројева, у граматикама и приручницима налазимо различита обавештења и препоруке. Док се већина аутора слаже са оценом да се збирни бројеви све ређе мењају у говору и писању ${ }^{5}$, у граматикама се, ипак, уз граматички опис дају и облици њихове промене. Када је реч о конгруенцији, збирни бројеви у једнини одговарају средњем роду (двоје/троје/четворо студената/деце/чељади долази / је дошло). Код семантичке конгруенције постоји разлика између „квантификативне именице које означавају скуп особа једног и другог пола [код којих је конгруентна реч у множини: двоје/троје/четворо студената долазе/су дошли] и збирне именице [са конгруентном речју у једнини: двоје/троје/четворо деце/пилади долазе]" (Поповић 1979: 22-23). О колебањима у слагању конгруентних речи са збирним бројевима у светлу развоја књижевнојезичке норме у новије време писано је и у Стијовић 2013: 229.

Узимајући у обзир оно што је досад казано у познатијим граматикама и литератури, а посебно оним новијим из друге половине прошлога века до данас, појмовни садржај термина збирни број и његово место у систему класификације разликује се од аутора до аутора. Повод за појмовно несагласје

${ }^{5} \mathrm{M}$. Стевановић тврди да се збирни бројеви све реће мењају у говору и делима писаца (Стевановић 1970: 323). У граматици Станојчић/Поповић (2007) пише да се збирни бројеви у савременом српском језику углавном употребљавају у основном облику, непромењеном (105), а исто се тврди и у граматици Р. Симића (2001: 168). Када је реч о нормативној препоруци, предност се даје говорном (и писаном) обичају већине, у којем преовладава одсуство промене ове бројне врсте (уп. Пипер/Клајн $\left.{ }^{2} 2014: 144\right)$. А. Стефановић (2017: 215) износи оцену да се у савременом српском језику не може потврдити постојање деклинираних бројева двоје и обоје. Сматрамо да се за први поменути пример изнета оцена не може без резерве прихватити, јер се промена броја двоје у текстовима аутора који држе до књижевнојезичке правилности и стила може наћи у немалом броју примера. 
лежи у питању множинских придевских облика, односно питање постојања бројних придева као посебне врсте бројева (уп. Зељић 2016: 27). Примећено je, међутим, да се, нарочито у последње време, и сам појмовни садржај термина бројни придев такође сужава у литератури, па се, тако, код једног броја аутора употреба бројног придева ограничава само на случајеве слагања (конгруенције) са именицама pluralia tantum, односно на именице којима се означава пар нечега (уп. нпр. Кликовац 2002: 89; Ломпар 2016: 288; Пипер/Клајн 2013: 138). Грађа коју смо прикупили за ово истраживање, међутим, показује да облици једнине и множине узети скупа употпуњују лексичко-граматичку структуру збирних бројева у целини, што ћемо, уз одабране примере, показати уопштавањем њихових значења:

1. (јд.) а. „збирни број долази уз збирне именице, обично оне које означавају збир младих бића, људи или животиња". - Мајка која има двоје мале дјеце ... чека сина да се врати из устанка (Дуч. Ј., РСАНУ, под двоје). Вићентије посла те дотераше деветоро говеда (Мил. М. Ђ., РСАНУ, под деветоро). б. „кад се заједно броји мушка и женска особа”. - Ђе двоје дише, треће се пише (Нар. посл., Вук);

2. (мн.) а. „Уз именице код којих се као јединка узима збирни појам у значењу скупа, групе, врсте нечега или као појам који се исказује само обликом множине". - Целокупној радњи ... служе поглавито: мозак ... даље дванаестори живци великога мозга (Куј., РСАНУ, под дванаесторо). Обукао си се у седмора небеса; скрио си се предубоко од свих очију (Велимировић 2003б: 34), Још је требало проћи двоја велика двокрилна врата (Гавр. А., РСАНУ). б. „уз именице којима се означава збир који се исказује обичном множином". - Они [коњи] су бољи него његови парадни, који сваки дан једу зоб и служе их десеторе слуге (НПр Чајк., РСАНУ, под десеторо). Њу ми просе сватови, | Деветори банови (НП Вук, РСАНУ, под деветоро). Изабрана [је] мати Југовића, деветорих синова који су најугледнији витези косовски (Поп. П., РСАНУ, под деветоро);

3. (самостално у јд., само за бројеве двоје и троје), „ве/три чињенице, ствари, две/три различите чињенице, ствари". - На Истоку, нарочито у Средњем истоку, „бити” је јаче наглашено него „радити” ... Савршенство лежи у јединству овога двога (Велимировић 2003a: 6). Наука наших дана бави се испитивањем три неслућена открића у физичкој природи. То су: атомска енергија, невидљива светлост и нечујни гласови. Ниједно од овога трога није доступно људским чулима (Велимировић 2003а: 6).

Лексичко-граматичка структура збирних бројева коју смо овде представили и примери којима смо издвојена значења илустровали показују да у категорији бројева преовладава граматичко значење над лексичким. Да је реч о превасходно граматичким значењима, говори чињеница да се под истом дефиницијом могу скупа подвести појединачни збирни бројеви. Ипак, разлика између збирних бројева употребљених у једнини (именичка форма средњег рода) и оних у множини (придевска форма у мушком, женском и средњем роду) може се у одређеним случајевима сагледати и из угла лексичке семантике: у једнини збирни бројеви долазе уз именице које означавају збир младих бића или особе мушког и женског пола узете у збиру, а у множини долазе 
1) уз именице које означавају збирни појам (од два или више ентитета), где се њихов лексички садржај може интерпретирати као тачан број скупова, група или врста нечега, односно 2) уз именице у обичној множини.

У наслову есеја И. Секулић, који гласи Чудан сусрет двојих писаиа, употребљен је придевски множински облик двоји, док је у самом чланку у сличном контексту употребљен основни број два: Преко текста у једном француском часопису дошло је до врло жива изроњавања једнога сећања, и онда, до сусрета између два писца који се никада нису видели, и неће (Секулић 2001: 360). Разлог због којег је ауторка баш у наслову чланка употребила број двоји, а не број два, који је у тексту после употребљавала, лежи у семантици, а не у граматици. Реч је о сусрету писаца који припадају културно и језички различитим народима - у питању је сусрет И. Секулић и америчког писца Џона Штајнбека - па се овај наслов уз употребу множинског облика двоји семантички може интерпретирати као сусрет двају народа, двеју култура, двеју књижевности итд. Употреба броја двоји у синтагми двоји писии наглашава да су у питању писци различитих народа, књижевности, језика и културе - дакле две ВРСТЕ писаца.

Навешћемо још један пример из дела И. Секулић: Балкански ратови, кажемо, донели су сјајне победе над двојим непријатељима, чаша поноса била је пуна, задовољство безмерно, освета Косова слатка (Секулић 2003, 276). Употреба збирног броја у множинском облику двоји уз именицу непријатељ означава да су у питању две непријатељске војске (дакле, умножена збирност) са којима је Србија ратовала у Првом и Другом балканском рату.

У примеру из Охридског пролога Светог владике Николаја: Имају тројu св. Врачи по имену Козма и Дамјан. Једни се мирно упокојише 1. новембра, други беше каменовани у Риму 1. јула, а ови трећи беху из Арабије (Велимировић 2008: 762), осим описном конструкцијом, збирни број у множинском придевском облику ниједним другим бројем није замењив. Реч је, дакле, о три пара свете браће, која су, сваки у своје време и у својим земљама, под истим именима, исцељивали болеснике именом Господа Исуса Христа. Једни се славе 1/14. јула, други 17/30. октобра, а трећи 1/14. новембра.

Слојевитост лексичко-граматичке структуре збирних бројева и, посебно, условљеност употребе морфолошког (граматичког) облика одређеном семантиком, разлог је постојања и очувања (негде мање, а негде више) двеју граматичких категорија (именичке и придевске), по нашем уверењу исте класе збирних бројева у српском језику.

\section{4. Збирни бројеви у описним речницима српског језика (приказ лексикографског заглавља збирних бројева)}

Главна карактеристика по којој се разликује приступ и обрада збирних бројева у трима речницима савременог српског језика јесте начин на који се представљају и описују њихови множински облици - почев од успостављања 
одреднице и граматичког описа речи, тј. броја, па до структуре речничког чланка и употребе граматичких термина. ${ }^{6}$

\section{Речник САНУ}

Лексикографски најдетаљније збирни бројеви су представљени у Речнику САНУ. Одредничку реч збирног броја чини број у основном облику једнине, а у лематском делу дати су граматички (морфолошки) подаци о облицима (једнина и множина) и њиховој промени, што се може илустровати следећим примерима узетих из Речника:

двоје (у јд. обично с) (ген. двога ... мн. двоји, двојих, двојим(а)) [двоје јарића, двоје мале дјеце, двоје гаће, двоја врата, двоје стубе, двоји сватови],

деветоро (у јд. непром.; мн. деветори, -е, -а) [деветоро браће, деветоро деце, деветоро говеда, деветори банови, деветори синови; у вечери деветора биља; отворена врата деветора; отворио ... деветоро очи, деветоре очи],

десеторо (у јд. непром.; мн. десетори, -е, -а) [десеторо момака и девојака; десеторо магаради; десеторо браће; с десеторо телади; десеторо деце; десеторе слуге; десеторе очи; десеторе стајаће хаљине; десеторе новине] итд.

\section{Речник МС}

У Речнику МС збирни бројеви су представљени на сличан начин као у Речнику САНУ. Одредничку реч збирног броја представља број у основном облику једнине, док се међу примерима наводе и облици у једнини и облици у множини. Множински облици збирних бројева издвојени су као одреднице, али оне нису посебно дефинисане (упућују на основни облик у једнини), нити су означене као друга врста бројева у односу на облике једнине. Издвајање множинских облика као посебних одредничких речи уз упућивање на основне облике у једнини није доследно спроведено у Речнику (издвојене су, на пример, петори, десетори, а нису осмори, троји, четвори).

\section{Речник српскога језика}

У Речнику српскога језика $\mathrm{MC}$ примењен је другачији поступак него у претходним двама речницима. Множински облици бројева на -оји, -ори издвојени су као посебне одреднице, које су описно и самостално дефинисане. У речничким дефиницијама множинских облика бројева није указано на морфолошки однос према облицима збирних бројева у једнини, што ћемо илустровати следећим примерима:

двоји, -е, -а мн. „бројни придев према основном броју два који се употребљава уз именице које имају само облике множине или означавају пар или две истоврсне групе

${ }^{6}$ Због уштеде простора примере из наведених речника нећемо давати у целости, већ у спојевима у којима се бројеви налазе. 
означене именицом у множини: наочари, $\sim$ врата, $\sim$ кола, $\sim$ чарапе,$\sim$ просиоци,$\sim$ сватови",

десетори, -е, -а мн. „бројни придев према броју десет, који се употребљава уз именице које имају само облик множине или уз именице које означавају парне појмове: врата, чарапе",

осмори, -е, -а „бројни придев према основном броју осам који се употребљава уз именице које имају само облике множине или означавају пар: врата, рукавице", петори, -е, -а мн. „бројни придев према основном броју пет који се употребљава уз именице које имају само облике множине или означавају пар: кола, панталоне, ципеле",

троји, е, -а мн. „бројни придев према основном броју три који се употребљава уз именице које имају само облике множине или означавају пар или три истоврсне групе означене именицом у множини: чарапе, $\sim$ виле, $\sim$ кола, $\sim$ просиоци” итд.

Пада у очи то да је у дефиницијама бројева двоји и троји дата могућност да бројеви стоје уз именице које означавају и „истоврсне групе означене именицом у множини", док је код других бројева то значење у дефиницији изостало, упркос потврдама датим у Речнику САНУ, као и њиховом опису у литератури. ${ }^{7}$

\section{5. Закључак}

На основу спроведене анализе збирних бројева и увида у релевантне граматике и литературу посвећену овој теми, дошли смо до следећих закључака.

Збирни бројеви на -оро/-ори и -оје/-оји у облицима једнине и множине представљају једну лексичко-граматичку класу бројева засновану на семантичкој компоненти збирности, као и заједничком делу основе -ој- и -ор-.

Збирни бројеви у једнини долазе уз именице које означавају збир младих бића (људи, животиња) или особе мушког и женског пола узете у збиру, а у множини стоје уз именице које означавају збирни појам (од два или више ентитета) или појам који се исказује само обликом множине, односно уз именице којима се означава збир који се исказује обичном множином.

Множински придевски облици бројева који долазе уз именице са значењем више ентитета узетих као целина (нпр. троји Свети врачи Козма и Дамјан) и уз именице којима се исказује обична множина (двоји писци, троји непријатељи итд.) данас готово сасвим изостају у описима бројева у граматикама и приручницима, без обзира на то да ли је реч о облицима који се посматрају као део збирних бројева или као независна класа под називом бројних придева. Сматрамо да множинске облике бројева на -ори, -оји у по-

${ }^{7}$ УП. нпр. следеће дефиниције: „Збирни бројеви у множини употребљавају се: а) уз именице које имају само множину: двоја врата, троје маказе, десетора кола; б) уз именице у множини, кад има неколико група таквих предмета у множини: троји нудиоци (= три групе нудилаца), петоре присталице (= пет група или врста присталица) и сл.” (Белић 2000а: 274-275) и опис бројних придева изнет у раду љ. Поповића (1979), где се за њих каже да се поред употребе уз именице плуралија тантум они употребљавају и уз именице за означавање парова, група и сл., дакле и тамо где се ,, иначе уз њих употребљавају основни бројеви” (15). 
менутим граматичким и семантичким функцијама не треба изостављати из нормативних граматичких описа и дефиниција бројева, будући да примери којима смо илустровали њихову употребу још увек припадају савременом књижевнојезичком стваралаштву.

Предлажемо да се множински облици на -оји, -ори не издвајају као посебна класа бројева истога ранга уз основне, збирне, редне и др. бројеве. Сматрамо да назив бројни придеви за означавање посебне врсте бројева није погодан ни из угла терминологије (притом, наглашавамо да овде мислимо само на назив врсте, а не као термин у другој употреби, где се бројни придев деценијама уназад употребљава). Име поменуте врсте садржи морфолошку ознаку у своме називу (придеви), чиме се нарушава семантичко класификационо начело које важи за именовање осталих врста (уп. колико има чега у збиру?, који је или које је што по реду? итд.).

Лексикографски најцеловитије и најдетаљније збирни бројеви су обрађени у Речнику САНУ, заједно са облицима једнине (у именичкој форми средњег рода) и множине (у придевској форми за сва три рода) као једном лексичкограматичком класом збирних бројева. На тај начин у Речнику је приказана њихова заједничка лексичко-граматичка структура, чиме је показана у одређеној мери међусобна веза између употребе једнинског, односно множинског облика збирног броја и значења које број у споју са именицом доноси.

\section{ИЗВОРИ}

Велимировић 2003а: Владика Николај, О Богу и људима, Ваљево: Глас Цркве. Велимировић 2003б: Владика Николај, Молитве на језеру, Ваљево: Глас Цркве.

Велимировић 2008: Владика Николај Велимировић, Охридски пролог, Ваљево: Епархија ваљевска, Манастир Лелић.

Нар. посл., Вук: Српске народне пословице ... скупио их и на свијет издао Вук Стеф. Караџић (државно издање), Биоград, 1900.

Речник MC: Речник српскохрватскога књижевног језика, Матица српска - Матица хрватска (I-III), Матица српска (IV-VI), Нови Сад - Загреб, 1967-1976.

Речник САНУ: Речник српскохрватског књижевног и народног језика, 1- , Београд: САНУ, 1959-.

PCJ: Речник српскога језика, Матица српска, Нови Сад, 2007.

Секулић 2001: И. Секулић, Језик и култура, Нови Сад: Stylos.

\section{ЛИТЕРАТУРА}

Барић и др. 1997: E. Barić i dr., Hrvatska gramatika, II. promijenjeno izdanje, Zagreb: Školska knjiga.

Белић 2000а: А. Белић, Историја српскохрватског језика (предавања др Александра Белића) у: Александар Младеновић (прир.), Историја срn- 
ског језика, Изабрана дела Александра Белића, 4. том, Београд: Завод за уџбенике, 153-486.

Белић 2000б: А. Белић, Граматика српскохрватског језика (за други разред средњих и стручних школа) [1934] у: Даринка Гортан-Премк (прир.), Граматике. О граматикама, Изабрана дела Александра Белића, 12. том, Београд: Завод за уџбенике, 95-178.

Зељић 2016: Г. Зељић, Морфолошко-семантичке карактеристике бројева у српском језику, Београд: Учитељски факултет.

Једличка 1977-1979: Slovník slovanské lingvistické terminologie/ Словарь славянской лингвистической терминологии / Dictionary of Slavonic Linguistic Terminology I-II, Alois Jedlička (red.), Academia Praha.

Јовановић 2017: В. Јовановић, Вредан прилог српској граматици (приказ књиге: Г. Зељић, Морфолошко-семантичке карактеристике бројева у српском језику, Београд: Учитељски факултет, 2016), Зборник Матище српске за књижевност и језик, 65, св. 1, Нови Сад, 295-299.

Кликовац 2002: Д. Кликовац, Граматика српскога језика за основну школу, Београд: Српска школска књига.

Лалевић 1951: М. С. Лалевић, Синтакса српског језика, Скрипта за студенте ВПШ, Београд.

Ломпар 2016: В. Ломпар, Врсте речи и граматичка пракса (од Вука до данас), Београд: Друштво за српски језик и књижевност Србије.

Маретић 1963: T. Maretić, Gramatika hrvatskoga ili srpskoga književnog jezika, Treće nepromijenjeno izdanje, Zagreb: Matica hrvatska.

Мразовић 2009: Pavica Mrazović, Gramatika srpskog jezika za strance, drugo, prerađeno i dopunjeno izdanje, Sr. Karlovci - Novi Sad: Izdavačka knjižarnica Zorana Stojanovića.

Пипер/Клајн 2013/2014: П. Пипер, И. Клајн, Нормативна граматика сриског језика, Нови Сад: Матица српска.

Поповић 1979: Љ. Поповић, Употреба кардиналних бројева у српскохрватском језику, Југословенски семинар за стране слависте, 30, Београд, $3-24$.

Радовић Тешић 2011: М. Радовић-Тешић, Граматички и лингвистички појмовник, Београд: Учитељски факултет Универзитета у Београду.

Симић 22001: Р. Симић, Српска граматика, I, Београд: МХ Актуел.

Станојчић/Пецо 1972: Енщиклопедијски лексикон. Српскохрватски језик, ред. Ж. Станојчић и А. Пецо, Београд: Интерпрес.

Станојчић/Поповић 1997: Ж. Станојчић, Љ. Поповић, Граматика српскога језика, Београд: Завод за уџбенике и наставна средства.

Станојчић 2008: Ж. Станојчић, Љ. Поповић, Граматика српскога језика, једанаесто, прерађено издање, Београд: Завод за уџбенике.

Стевановић 1970: М. Стевановић, Савремени српскохрватски језик, I, Београд: Научна књига.

Стефановић 2017: А. Стефановић, Деклинација збирних бројева и бројних придева, Научни састанак слависта у Вукове дане, 46/1, Београд, 213-224. 
Стијовић 2013: Р. Стијовић, Колебања у употреби збирних бројева у светлу развоја књижевнојезичке норме, Научни састанак слависта у Вукове дане, 42/1, Београд, 229-237.

Taфpa 1989: B. Tafra, Što su brojevi? (gramatički i leksikografski problem), $R a$ sprave ZJ, sv. 15, Zagreb, 219-237.

Владан 3. Йованович

СОБИРАТЕЛЬНЫЕ ЧИСЛИТЕЛЬНЫЕ В ГРАММАТИКЕ И ЛЕКСИКОГРАФИИ

Резюме

В статье анализируются собирательные числительные как один из типов в классификации числительных в сербской грамматике. Принимая во внимание тот факт, что в грамматической литературе и толковых словарях сербского языка класс собирательных числительных не описан одинаково, в этой статье внимание посвящено понятным, терминологическим и классификационным вопросам собирательных числительных в системе категории числительных в сербской языковой науке. Собирательные числительные в этой статье рассматриваются как один лексикограмматический класс числительных на -оје (-ојu) и -оро (-ори), которые связаны с семантической собирательной компонентой и частью основы -ој- и -ор-. Анализ проводился в следующих областях: 1) собирательные числительные в грамматической литературе; 2) грамматический и семантический анализ собирательных числительных, 3) обработка и представления собирательных числительных в толковых словарях сербского языка.

Ключевые слова: имя числительные, собирательные числительные, классификация, грамматика, „бројни придев”, лексико-граматический анализ, лексикография, сербский язык. 